\title{
Post-weaning performance of East Friesian cross ewe lambs grazing ryegrass or plantain-based pastures after rearing on two
} contrasting diets

D.R. STEVENS ${ }^{1}$, F.W. $\mathrm{KNOL}^{2}$, B.A. NEIPER ${ }^{2,3}$ and S.A. McCOARD ${ }^{2}$ ${ }^{1}$ AgResearch, Invermay Research Centre, Private Bag 50034 Mosgiel, New Zealand ${ }^{2}$ AgResearch, Animal Nutrition \& Physiology Team, Grasslands Research Centre, Tennent Drive, 4442 Palmerston North, New Zealand

${ }^{3}$ Massey University, Institute of Veterinary, Animal and Biomedical Sciences, Tennent Drive, 4474 Palmerston North. New Zealand

david.stevens@agresearch.co.nz

\section{Abstract}

Artificial rearing is used routinely on dairy sheep farms. Different strategies are used to optimise the growth and development of the young lamb with an economic ration of milk and other feed components. Early weaning, and early introduction to pasture can both reduce these costs, but may also reduce the liveweight gains of the growing lamb. Can differences in pre-weaning feeding strategies be mitigated using specialist pastures such as plantain/red/white clover? Lambs from an experiment investigating the impacts of rearing with and without meal access ( $n=30 /$ group) and weaned at 12 weeks of age were grazed on either perennial ryegrass-based or plantain/red clover-based pastures in 3 replicates. Liveweight gain, animal health, feed supply and feed quality parameters were recorded over the following 5 weeks. Liveweights of the lambs reared on the different feeding regimens were similar at 12 weeks of age when the grazing study began $(25.9 \mathrm{~kg})$. Using plantain/red clover-based pastures provided no advantage to the liveweight gain of lambs reared under different milk and concentrate feeding regimens. Both feed types provided adequate nutrition to ensure growth rates of approximately $180 \mathrm{~g} /$ day over the 5 week measurement period in late spring. However, lambs reared under a high concentrate system has consistently lower liveweight gains $(160 \mathrm{~g} /$ day $)$ over the 5 weeks than those lambs reared with access to pasture $(200 \mathrm{~g} /$ day; $\mathrm{P}<0.05$ ). Feed quality was high on both pasture types. Symptoms of photosensitivity were recorded on both pasture types, but predominantly in lambs reared with ad libitum access to meal until week 10 of life, posing a question over functional liver development. This may have also affected liveweight gain.

Keywords: artificial rearing, lamb liveweight gain ryegrass, plantain, post-weaning

\section{Introduction}

The sheep dairy industry in New Zealand is undergoing

a resurgence with the emergence of several exporting enterprises (Stevens \& Bibiloni 2014). Farms servicing these enterprises aim to harvest as much milk as possible by artificially rearing lambs from 2 days old, after they have received colostrum from their dams. A range of feeding several times day to automatic on-demand feeder systems. Current practice also includes access to grain-based meal an fibre in the form of chaff or hay. Compared to young ruminants fed a milk only diet, early access to solid feed stimulates rumen development (Baldwin et al. 2004) and earlier onset of rumination (Khan et al. 2016) with the aim of early weaning off milk replacer (Bimczok et al. 2005). In lambs, earlier rumen development via pasture and increased rumination, thereby supporting early weaning and reduced cost.

Post-weaning intake and growth are a direct response to the ability of the rumen to process grass (Joyce \& Rattray 1970). Thus, pre-weaning development of the rumen is paramount to subsequent success (Khan $e t$ al. 2016). Current practices are based on international research, where lambs are often kept within housed systems and fed grain-based total mixed rations both in New Zear in New Zealand where weaning to pasture only diets is most common and preferred. Given that the digestive microbial population for grain-based diets are differen from those required to digest pasture (Hungate 1966), then is it wise to rear lambs on meal, but when do they then need to be transferred to pasture? Once these lambs are weaned, then does the type of pasture offered influence the liveweight of those lambs? The experiment influe he live liveweight gain of la bs reared with ad pobinu access to meal compared to those with access to pasture only during the pre-weaning phase, and then offered either a ryegrass or plantain-based pasture during the 5 weeks after transition to a pasture only diet.

Materials and methods

A study investigating two pre-weaning feeding 
strategies was conducted at AgResearch Limited Grasslands in Palmerston North, New Zealand (see Jensen et al. 2016 for details). Briefly, East Friesian cross-bred ewe lambs $(n=60)$, aged 3 days, were reared indoors (average weight $4 \pm 0.2 \mathrm{~kg}$ ) using continuou access to milk (Anlamb, NZAgbiz Ltd, Timaru, New Zealand; mixed at $230 \mathrm{~g} / \mathrm{L}$ ) fed via an automatic feeder (CalfMom ALMA Urban Feeder, PPP industries, Tuakau, New Zealand) for 3 weeks. The lambs were grouped in two cohorts. One had ad libitum access to meal for 9 weeks, while the other had no meal. After 3 weeks both cohorts were transferred to outdoor pasture with continued access to milk replacer through a cafeteria system, replenished twice a day. Both groups were weaned from milk at 5 weeks of age (meal-fed lambs, $18 \mathrm{~kg}$ on average; no meal lambs, $17 \mathrm{~kg}$ ). Meal access was removed over a 10 days at a rate of $10 \%$ per day in weeks 10 and 11 . The measurement period continued until the end of week 12 when final liveweights were recorded (Jensen et al. 2016).

The lambs from meal or pasture treatments were allocated to two new feeding treatments, ryegrass or plantain-based pasture in three replicates, balanced for litter size. Lamb liveweight gain was measured weekly over the following 5 weeks. Herbage mass was estimated from uncompressed sward height using the equations developed by Haultain et al. (2014). Pregrazing herbage mass averaged approximately 3000 and $2600 \mathrm{~kg} \mathrm{DM} / \mathrm{ha}$ on ryegrass and plantain-based pastures, respectively. Lambs were shifted weekly to a fresh allocation of pasture, leaving a residual herbage mass of 1400-1700 kg DM/ha. Pastures were sampled for botanical composition and feed quality. The chemical composition of pastures was analysed by Near Infrared Reflectance Spectroscopy (Nutrition

Table 1 Post-weaning average daily liveweight gains of ewe lambs from 12 to 17 weeks
of age when offered either ryegrass or plantain-based pastures, and the botanical composition (\% of DM) of those pastures.

\begin{tabular}{lcccc}
\hline & \multicolumn{4}{c}{ Post-weaning pasture } \\
\cline { 2 - 5 } & Ryegrass & Plantain/clover & $\mathbf{P}$ & SED \\
\hline Average daily gain (g/d) & 181 & 187 & 0.73 & 15.0 \\
OMD (g/100g DM) & 74.1 & 81.3 & $<0.01$ & 1.6 \\
ADF (g/100g DM) & 25.1 & 21.2 & $<0.01$ & 1.0 \\
NDF (g/100g DM) & 48.3 & 36.4 & $<0.01$ & 1.6 \\
CP (g/100g DM) & 18.5 & 22.6 & $<0.01$ & 1.3 \\
White clover (\%) & 3 & 20 & $<0.01$ & 1.2 \\
Red clover (\%) & 0 & 11 & $<0.01$ & 1.7 \\
Grass/plantain leaf (\%) & 43 & 34 & 0.19 & 5.9 \\
Grass/plantain stem (\%) & 40 & 4 & $<0.01$ & 4.7 \\
Dead material (\%) & 12 & 25 & 0.07 & 5.2 \\
Other species (\%) & 1 & 6 & 0.39 & 5.0 \\
\hline
\end{tabular}

Laboratory, Massey University, Palmerston North, New Zealand). This procedure was not calibrated for plantain-legume mixtures.

Lambs were assessed for health status daily. A preventative treatment for internal parasites was administered at 8 and 12 weeks of age with Zolvix Plus (monepantel $25 \mathrm{~g} / \mathrm{L}$, abamectin $2 \mathrm{~g} / \mathrm{L}$ administered at $1 \mathrm{ml} / 10 \mathrm{~kg} \mathrm{LW})$. One outbreak of coccisidiosis was recorded at week 12 and all lambs were treated (Baycox C. $50 \mathrm{mg} / \mathrm{ml}$ Toltazuril at $3 \mathrm{ml} / 10 \mathrm{~kg}$ LW) Five lambs were diagnosed to have spring eczema in early December after swelling and lesions on the ears and nose indicated photosensitivity. The ears and nose of all lambs were treated with FiltaBac (active ingredients: Titanium dioxide USP 14\%, Zinc oxide BP $8 \%$, Cetrimide BP USP $0.3 \%$, Benzalkonium chloride $0.08 \%$ ), a topical treatment for spring eczema, on December $2^{\text {nd }}$ and $9^{\text {th }}$ One lamb died of torsion and displacement of the intestine (redgut) after 4 weeks on plantain.

Data were analysed using REML with pasture and rearing method as the main treatments applied in a factorial design with 3 replicates. Average daily liveweight gain for individual lambs was calculated by linear regression over 5 weeks to reduce week to week variation in individual liveweight measurements before being analysed.

\section{Results}

Lambs entered the experiment at an average of 25.2 $\mathrm{kg}$ at 12 weeks of age. Lambs that had been reared on meal had been losing weight at approximately $60 \mathrm{~g} / \mathrm{d}$ in the 2 weeks before this (Jensen et al. 2016), despite being on high quality pastures of approximately 11.3 MJ ME/kg DM. Lamb liveweight gain during 5 weeks was unaffected by pasture type (Table 1) averure type (Table 1) averging Feed qulity 185 g/day. Feed quality was high on both pasture types, though consistently higher on the plantain-based pastures (Table 1) with consistently higher organic matter digestibility (OMD), lower $\mathrm{ADF}$ and NDF, and higher ADF a crude protein (CP) concentrations. The percentage of both white and red clover were higher in the plantain than ryegrass pastures (Table 1). The percentage leaf on both ryegrass and plantain was similar, though ryegrass had much higher stem contents that plantain. There was a trend for plantain pastures to have more dead material than ryegrass pastures $(\mathrm{P}=0.068)$.

Lambs fed no meal were lighter than lambs from the meal treatment when measured at 12 weeks of age. This difference was no longer present at 17 weeks of age (Table 2). Previous rearing method significantly influenced lamb liveweight gain (Table 3). Lambs reared with ad libitum access to meal grew at approximately $160 \mathrm{~g} / \mathrm{day}$ while ith no access to meal grew at $200 \mathrm{~g} /$ day $(\mathrm{P}=0.05)$.

Animal health records indicated that lambs reared on ad libitum access to meal were more vulnerable to problems (Table 3). Visual symptoms of coccidiosis were significantly greater in lambs reared on meal than on pasture. Clinical symptoms of summer eczema were numerically higher in meal-reared lambs than pasturereared lambs ( 12 versus $5 \% ; \mathrm{P}=0.120)$, but did not differ in a statistical sense.

\section{Discussion}

The similarity of lamb growth on the ryegrass and plantain-based pastures was somewhat surprising given the large differences in clover content. However, Sinhadipathige et al. (2012) also found no increase in lamb liveweight gain of 11 month old lambs grazing these pasture types in spring. Other researchers have also noted little advantage to either of these types of high quality pastures during spring, when ryegrass quality is high (Semiadi et al. 1993; Stevens et al. 2012; Cranston et al. 2016). The high allowance and residual pasture mass will have ensured that lambs had an adequate diet selection ensuring high growth rates on both pasture types. However, the large amounts of grass stem in the ryegrass pasture, and dead material in the plantain/clover pasture are known to reduce lamb growth (Lambert \& Litherland 2000).

This experiment has demonstrated that the rearing method of lambs can have an important influence on performance post-weaning. performance post-weaning.
Though liveweights of Though liveweights of
the lambs were slightly different at the start of the experiment, this does not suggest that compensatory gain was a cause of the difference in liveweight

Table 3 gain during the experiment. While previous studies ave shown that meal feeding is advantageous to rumen development, this has often been for continuous rearing on, at least partial, concentrate diets. Cristobe et al. (2016) reported few differences in the volatile fatty acid composition of rumen contents at 4 or 12 weeks of age on restricted or ad libitum milk intakes, though ammonia concentration was higher in lambs with restricted access to milk. Rearing young calves and subsequent high post-weaning performance on pasture (Muir et al. 2001).

Using a meal ration as the starting point for rumen development means that lambs must wean from milk, and then transition from meal. The meal intakes of lambs before removal from the diet were approximately $500 \mathrm{~g} / \mathrm{lamb} / \mathrm{day}$, even when offered pasture of high quality (Jensen et al. 2016), and liveweight change of lambs during the transition from meal was negative (Jensen et al. 2016).

Of concern was the animal health responses of lambs reared with ad libitum access to meal. The outbreak of coccidiosis is a common occurrence in lambs reared on milk replacer when weaned to pasture (Foreyt 1990). One potential mechanism for the difference in incidence between the two rearing methods suggested by Hoblet et al. (1989), was that the potential, low exposure to the disease when the pasture only lambs had low intakes, may have provided some protection to later exposure to the disease.

The cause of spring eczema is still unknown (Collett

Table 2 Liveweight at 17 weeks of age of lambs reared with or without meal, and then placed on either ryegrass or plantain/clover pastures after weaning.

\begin{tabular}{lcccccc}
\hline & \multicolumn{2}{c}{ Ryegrass } & \multicolumn{2}{c}{ Plantain/clover } & \multicolumn{2}{c}{$\begin{array}{c}\text { Pre-weaning } \\
\text { Main effects }\end{array}$} \\
\cline { 2 - 8 } & No meal & Meal & No meal & Meal & P & SED \\
\hline Lamb liveweight (kg) & & & & & & \\
12 weeks old & 25.2 & 26.6 & 23.9 & 25.2 & 0.03 & 0.47 \\
17 weeks old & 32.2 & 32.3 & 31.0 & 31.2 & 0.14 & 0.69 \\
\hline
\end{tabular}

Post-weaning daily liveweight gain of ewe lambs from weeks 12 to 17 of age after rearing with or without ad libitum access to meal, and incidence of coccidiosis and rearing with or without ad libitur
spring eczema during that time.

\begin{tabular}{lcccc}
\hline & \multicolumn{4}{c}{ Pre-weaning treatment } \\
\cline { 2 - 5 } & No meal & Meal & P & SED \\
\hline Average daily gain (g/day) & 202 & 166 & 0.05 & 15 \\
Coccidiosis (\%) & 5 & 33 & 0.02 & 8 \\
Spring eczema (\%) & 3 & 12 & 0.12 & 5 \\
\hline
\end{tabular}


2006). Putative causes include an acquired inability of the liver to process a high loading of chlorophyll after liver damage (e.g. sporidesmin poisoning), or immaturity of the liver (Collett 2006). However, in calves it is suggested that it is 'inherent'. Collett (2006) has suggested that it may be associated with dietary ingredients such as storksbill (Erodium moschatum) However, evidence from this study suggests that it may be related to high intakes of meal or low intakes may be relating

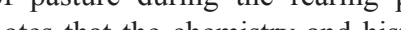
notes that the chemistry and histology of the liver do not show obvious signs in response to the disease Combined with the results from this study, this would suggest that the development of the rumen may be more important. Exposure to pasture and chlorophyll during early rumen development may be a mitigating factor, and this may affect the health of the animal upon exposure to high pasture intakes.

This research provides some potential insights into the role of rumen development beyond the standard criteria of diet digestion and liveweight gain. Further research is required to build on these findings to improve understanding of the function and interaction between the rumen microbes and their host, the ruminant.

\section{Conclusions}

The processes of lamb rearing for large scale sheep dairy in New Zealand present many challenges. One of these is the ability to rear a lamb quickly and cost effectively to the point where it can achieve adequate nutrition from pasture. This study has identified one approach that may have merit. However, the logistics of providing fresh, clean pasture to hundreds or thousand of lambs each rearing season will have its own challenges. Therefore, while the early access to pasture provides some important benefits, those raising lambs should choose systems that allow a balance between cost, hygiene and nutrition that suits their needs.

\section{ACKNOWLEDGEMENTS}

This study was funded by the Ministry of Business Innovation \& Employment (MBIE; contract C10X1305), in partnership with Kingsmeade Artisa Cheese, Maui Milk and Spring Sheep Dairy. Thanks to the Animal Nutrition \& Physiology Team and UlyattReid Large Animal Facility staff for their assistance with animal care and data collection.

\section{REFERENCES}

Baldwin, R ; McLeod, K.; Klotz, J.; Heitmann, R. 2004 Rumen development, intestinal growth and hepatic metabolism in the pre- and post-weaning ruminant. Journal of Dairy Science 87: 55-65.

Bimczok, D.; Rohl, R.W.; Ganter, M. 2005. Evaluation of lamb performance and costs in motherless rearing of German Grey Heath sheep under field conditions using automatic feeding systems. Small Ruminant Research 60: 255-265.

Collett, M.G. 2004. Spring eczema in ruminants in New Zealand. New Zealand Veterinary Journal 53: 93-94. Collett, M.G. 2006. Spring eczema: the search for the cause(s) continues. New Zealand Veterinary Journal 54: 50.

Cranston, L.M.; Corner-Thomas, R.A.; Kenyon, P.R. Morris, S.T. 2016. Growth of early weaned lambs on a plantain-clover mix compared with lambs suckling their dam on a plantain-clover mix or grass based sward. Proceedings of the New Zealand Animal Production Society 76: 65-68.

Cristobel-Carballo, O.; Khan, M.A.; Knol. F.W.; Lewis, S.J.; Stevens, D.R.; McCoard, S.A. 2016. Impact of early weaning on rumen fermentation profiles of artificially reared lambs. Proceedings of the New Zealand Society of Animal Production 77: 49-54.

in sheep and goats. Veterinary Clinics of North America: Food Animal Practice 6: 655-670.

Haultain, J.; Wigley, K.; Lee, J.M. 2014. Rising plate meters and a capacitance probe estimate the biomass of chicory and plantain monocultures with similar accuracy as for ryegrass-based pastures. Proceedings of the New Zealand Grassland Association 76: 67-

Hoblet, K.H. Charles, T.P. Howard, R.R. 1989. Evaluation of lasalocid and decoquinate against coccidiosis resulting from natural exposure in weaned dairy calves. American Journal of Veterinary Research 50: 1060-1063.

Hungate, R.E. 1966. The rumen and its microbes. Academic Press, New York. 533 pp.

Jensen, A.C.; Khan, M.A.; Knol, F.W.; Peterson, S.W.; Morel, P.C.H.; Lloyd-West, C. Stevens, D.R.; McCoard, S.A. 2016. How does feeding meal affect growth of artificially reared East Friesian-cross dairy lambs? Proceedings of the New Zealand Animal Production Society 77: 13-17.

oyce, J.; Rattray, P. 1970. The intake and utilization of milk and grass by lambs. Proceedings of the New Zealand Society of Animal Production 30: 94-105.

Khan, M.A.; Bach A.; Weary D.M.; Von Kerserlingk, M.A.G. 2016. Invited Review: Transitioning from milk to solid feed in dairy heifers. Jounal of Daiy Science 99: 885-902. Lambert, M.G.; Litherland, A.J. 2000. A practitioner's guide to pasture quality. Proceedings of the New Zealand Grassland Association 62: 111-116.

Muir, P.D.; Nieuwenhuis, G.; Smith, N.B.; Ormond, A.W.A. 2000. A comparison of rearing systems for dairy beef calves. Proceedings of the New Zealand Grassland Association 62: 9-11.
Neiper, B.A.; Khan, M.A.; Ganish, S.; Knol, F.W.; Peterson, S.W; Stafford, K.J; Stevens, D.R. McCoard, S.A. 2016. The effects of early access to solid feed on rumination and feeding behaviour of artificially reared dairy lambs. Proceedings of the New Zealand Animal Production Society 77: 18-22.

Sinhadipathige, S.C.C.; Kenyon, P.R.; Kemp, P.D.; Morris, S.T.; Morel, P.C.H. 2012. Can herb-clover mixes increase lamb liveweight gains in spring? Proceedings of the New Zealand Grassland Association 74: 137-142.

Semiadi, G.; Barry, T.N.; Wilson, P.R.; Hodgson, J.; Purchas, R.W. 1993. Growth and venison production from red deer (Cervus elaphus) grazing red clover (Trifolium pratense) or perennial ryegrass (Lolium perenne) white clover (Trifolium repens) pasture. Journal of Agricultural Science, Cambridge 121: 265-271.

Stevens, D.; Bibiloni, R. 2014. The emerging dairy sheep industry in New Zealand. Options Mediterraneennes A 109: 741-743.

Stevens, D.R.; Thompson, B.R.; Carruthers, A.; Wall, A.J.; Casey, M.J.; Phiskie, R.; Young, P.; Moot, D.J. 2012. Understanding the role of spring grazing of ucerne in the Central Otago environment. Proceedings of the New Zealand Grassland Association 74: 69-76. 